\title{
HUMOR GRÁFICO, MEMÓRIA, IDENTIDADE SOCIAL E A FIGURA DO INTELECTUAL ORGÂNICO EM HENFIL E QUINO
}

\author{
Renato Fonseca Ferreira ${ }^{1}$
}

\begin{abstract}
RESUMO: O presente trabalho tem por objetivo analisar 6 cartuns e tiras cômicas de cunho político executados por Henfil e Quino em meados das décadas de 1960 e 1970 tendo como referência questões relacionadas à memória, a representação de classes, a identidade social e gênero e, identificados em um período das ditaduras brasileira e argentina. A pesquisa visa elucidar como estes gêneros do humor gráfico criam múltiplos pontos de vista a respeito do tratamento das questões políticas e a formação do intelectual orgânico, percebendo-se que as relações entre as representações dos cartunistas estão inter-relacionadas com saberes, com ideologias e marcadas por dialogismos, produzindo novos significados por meio dos traços do desenho e da linguagem utilizada. A partir das considerações nas análises das imagens, percebem-se proposições complexas que são exibidas em um plano de compreensão popular viabilizada por uma linguagem simples e direta. Assim, a partir das imagens apresentadas neste trabalho, identificamos que as formações ideológicas dos cartunistas subvertem o sentido como elementos de identidade, ligadas à figura do intelectual orgânico (GRAMSCI, 2001) e utilizando-se de metáforas visuais e verbais para dizer algo a mais.
\end{abstract}

PALAVRAS-CHAVE: Henfil; Quino; intelectual orgânico; memória.

\section{HUMOR GRAPHIC, MEMORY, SOCIAL IDENTITY AND THE FIGURE OF THE ORGANIC INTELLECTUAL IN HENFIL AND QUINO}

\begin{abstract}
The present work aims to analyze 6 cartoons and political comic strips executed by Henfil and Quino in the middle of the 1960s and 1970s with reference to issues related to memory, class representation, social identity and gender and, identified in a period of Brazilian and Argentine dictatorships. The research aims to elucidate how these genres of graphic humor create multiple points of view regarding the treatment of political issues and the formation of the organic intellectual, perceiving that the relations between the representations of the cartoonists are interrelated with knowledge, ideologies and marked by dialogisms, producing new meanings through the traces of the design and the language used. From the considerations in the analysis of the images, one can perceive complex propositions that are displayed in a plane of popular understanding made possible by a simple and direct language. Thus, from the images presented in this work, we see that the ideological formations of the cartoonists subvert the sense as elements of identity, linked to the figure of the organic intellectual (GRAMSCI, 2001) and using visual and verbal metaphors to say something more.
\end{abstract}

KEYWORDS: Henfil; Quino; organic intelectual; memory.

\footnotetext{
${ }^{1}$ Mestre em Arte e Cultura Visual pela Universidade Federal de Goiás (UFG). Coordenador do Curso Superior Tecnológico em Design Gráfico da Universidade Paulista (UNIP). Docente na Pontifícia Universidade Católica de Goiás (PUC-Goiás).
} 


\title{
HUMOR GRÁFICO, MEMORIA, IDENTIDAD SOCIAL Y LA FIGURA DEL INTELECTUAL ORGÁNICO EN HENFIL Y QUINO
}

\begin{abstract}
RESUMEN: El presente trabajo tiene por objectivo analizar 6 cartuns y tiras cómicas de cuño político llevado a cabo por Henfil y Quino a mediados de las décadas de 1960 y 1970 teniendo como referencia cuestiones relacionadas a la memoria, la representación de clases, la identidad social y género $\mathrm{y}$, identificados en un período de las dictaduras brasileña y argentina. La investigación pretende elucidar cómo estos géneros del humor gráfico crean múltiples puntos de vista acerca del tratamiento de las cuestiones políticas y la formación del intelectual orgánico, percibiendo que las relaciones entre las representaciones de los cartunistas están interrelacionadas con saberes, con ideologías y ideologías marcadas por dialogismos, produciendo nuevos significados por medio de los rasgos del diseño y del lenguaje utilizado. A partir de las consideraciones en las análisis de las imágenes, se percibe proposiciones complejas que se exhiben en un plano de comprensión popular viabilizada por una lenguaje simple y directa. Así, a partir de las imágenes presentadas en este trabajo, identificamos que las formaciones ideológicas de los cartunistas subvierten el sentido como elementos de identidad, ligadas a la figura del intelectual orgánico (GRAMSCI, 2001) y utilizando metáforas visuales y verbales para decir algo más.
\end{abstract}

PALABRAS CLAVE: Henfil; Quino; intelectual orgánico; la memoria.

\section{INTRODUÇÃO}

A recorrência a elementos verbais e a construção de valores históricos e sociais tornam o cartum ${ }^{2}$ e as tiras cômicas ${ }^{3}$ em um dispositivo interdisciplinar portadores de um discurso persuasivo e ideológico que utiliza o humor como ferramenta de orientação crítica e de protesto. O humor presente no cartum, nas tiras e nos variados gêneros do humor gráfico, não pressupõe uma atitude negativa, mas é justamente a constituição humorística que permite a

\footnotetext{
${ }^{2} \mathrm{O}$ termo cartum é uma variação em português do termo original em inglês cartoon (cartão) que, por sua vez, origina-se no termo italiano cartone (grande pedaço de papel). Segundo Fonseca (1999), esse material era aplicado aos moldes recortados ou perfurados em cartão resistente, usados para transpor e marcar os desenhos nas obras de arte de grande porte, como murais ou tapeçarias. O mesmo termo também era utilizado para definir projetos artísticos que posteriormente seriam ampliados. O sentido da expressão atual surgiu pela primeira vez na revista Punch na década de 1840 que reuniu um grupo de artistas em exposição para satirizar os acontecimentos políticos da época. Fonseca (1999) afirma que o termo cartoon não possui correspondência em outras línguas. Neste sentido, a grafia original inglesa é mantida em países como Alemanha, França ou Espanha. No Brasil, foi na revista Pererê, de Ziraldo, em fevereiro de 1964, que foi criado o neologismo cartum tornandose um jargão profissional e designativo da função cartunista. Fonseca (1999) define o cartum com um desenho caricatural que apresenta uma situação humorística.

${ }^{3}$ Conforme Fonseca (1999), as tiras cômicas são pequenas histórias compostas por quadros sequenciais sendo uma das categorias de humor gráfico. O elemento básico da tira é o painel, sendo um desenho simples, encerrado em uma moldura, agrupados em três ou mais painéis de uma forma extensa, em sequência ou episódios podendo ter a inclusão de elementos das histórias em quadrinhos como: balões de fala e pensamentos, signos, símbolos e onomatopeias.
} 
Humor gráfico, memória, identidade social e a figura do intelectual orgânico em Henfil e Quino

Renato Fonseca Ferreira

ele, dissimulando seu caráter de oposição, tentar desvelar, pela linguagem verbal e não-verbal, sentidos muitas vezes silenciados no contexto político (D’ATHAYDE, 2010).

Segundo Minois (2004), o humor escapa a definições, porém adquire formas típicas de uma determinada nação e cultura contribuindo para formas diferenciadas de humor: humor americano, humor alemão, humor inglês etc. A linguística aponta o humor num discurso como forma de não dizer ou silenciar algo (ORLANDI, 2009).

D’Athayde (2010) demonstra que o discurso ideológico presente tanto no cartum e nas tiras quanto nas charges ${ }^{4}$, considera o humor como uma função desestabilizadora de sentidos, a qual revela aquilo que não é dito diretamente, mantendo um posicionamento de protesto e rebeldia, tornando compreensível aquilo que é exposto. Assim, o cartum e as tiras estabelecem um padrão de comunicação universal que promove uma identificação quase imediata do indivíduo ou fato retratado em seu interior por ser constituída de signos que podem ser interpretados de acordo com o conhecimento de cada indivíduo, ou ainda, por uma memória histórica que é também coletiva.

O presente trabalho visa a análise de 6 (seis) cartuns e tiras cômicas de cunho político executados por Henfil e Quino e veiculadas nos periódicos como O Pasquim e o El Mundo, tendo como referência os principais acontecimentos relacionados à memória, a representação de classes, a identidade social e gênero. A escolha de Henfil e Quino justifica-se devido à representatividade que estes cartunistas exercem no âmbito da produção em humor gráfico no Brasil e na Argentina, principalmente durante os anos das ditaduras ${ }^{5}$. Logicamente, há outros cartunistas que contribuíram para a constituição do humor gráfico, porém estes desenhistas representam o amadurecimento do humor gráfico através de uma nova geração pós anos 1970.

Por meio do conceito de hegemonia e formação do intelectual orgânico, desenvolvido por Gramsci (2001) e as relações entre política e sociedade no materialismo histórico, destacamos as relações entre infraestrutura (condições de trabalho ou relação entre o proletariado e a burguesia) e superestrutura (papel social, instituições do Estado e a cultura)

\footnotetext{
${ }^{4}$ A charge é um termo francês, cujo significado vem de carregar, exagerar ou atacar violentamente. Uma representação de caráter burlesco e caricatural, segundo Fonseca (1999).

${ }^{5}$ A Argentina teve uma situação semelhante à do Brasil em relação a um governo militar e ditador, tendo início em 1966 por meio de um golpe militar, depondo o presidente Arturo Illia em junho de 1966. Embora o tempo de vigência da ditadura argentina tenha sido de apenas 7 anos - no Brasil foram 21 anos - durante os governos do general Juan Carlos Onganía, o general Roberto Marcelo Levingston e o general Alejandro Agustín Lanusse, houve mais de 30 mil civis mortos a vigência do golpe. No Brasil, o presidente João Goulart foi deposto de seu cargo no final do mês de março de 1964, esboçando três diferentes fases por meio da oficialização do regime, repressão e violência aos opositores e reabertura política. Segundo fontes da Folha (2018), cerca de 434 pessoas foram mortas ou desapareceram durante os anos da ditadura.
} 
nas representações de Henfil e Quino e as denúncias oriunda delas. Assim, podemos mencionar através das imagens, a necessidade de mudança histórica na passagem para uma nova ordem social. As transformações sociais denunciadas por meio dos cartuns e das tiras cômicas, podem revelar o processo de desmantelamento da velha ordem e reposição da hegemonia e da dominação burguesa $^{6}$ que são caracterizados no conceito de revolução passiva (MACIEL, 2010).

A observação dos cartuns e tiras implica em pensar vários aspectos que as envolvem como a historicidade, o humor, a técnica e as reflexões que colocam o leitor em contato com sua época. E, a partir destas considerações, podemos perceber que o cartum/ tira é um dispositivo que ao mesmo tempo possui uma carga midiática e também artística e o humor funciona como um mecanismo de desarticulação do sentido normatizado, contudo os consideramos como campo híbrido que reflete perspectivas sócio históricas, comunicativas e expressivas.

\section{HENFIL}

Henrique de Souza Filho, o Henfil, nasceu em 5 de fevereiro de 1944 em Ribeirão das Neves - MG, atuando como cartunista, jornalista e escritor. Em 1964, quando, a convite do editor e escritor Robert Dummond, começou a trabalhar na revista Alterosa, de Belo Horizonte, criando "Os Franguinhos" (CENTRO CULTURAL SÃO PAULO, GIBITECA HENFIL, 2018). Em 1965, colaborou com o jornal Diário de Minas, produzindo caricaturas políticas. Em 1967, criou charges esportivas para o Jornal dos Sports, do Rio de Janeiro. Também teve seu trabalho publicado nas revistas Realidade, Visão, Placar e $O$ Cruzeiro e a partir de 1969, passou a colaborar com o Jornal do Brasil e com O Pasquim:

Dessa forma, tentaremos interpretar os cartuns e as tiras, sem a intenção de buscar um sentido "verdadeiro", mas um sentido estabelecido por padrões históricos e ideológicos, materializados no discurso das imagens e construídos pelo cartunista. Isto, segundo Orlandi (2009), consiste em um processo de interpretação do objeto de análise, em que se deve não apenas descrever o sentido constituído nele, através de fontes externas, trabalhando em uma posição que não seja neutra e permitindo ultrapassar a obviedade da linguagem, mas perceber

\footnotetext{
${ }^{6}$ As definições para o termo burguesia possuem significados históricos, sociais e culturais diversos. O sentido empregado nesta afirmação, para dialogar com os diversos autores marxistas, está associado à uma classe detentora dos meios de produção ou às classes dominantes na sociedade capitalista.
} 
as particularidades metafóricas, o equívoco, a concordância. Em outras palavras, entendemos o processo de interpretação como um todo, seja ele do ponto de vista do sujeito-cartunista ou do sujeito-leitor. Momento em que nos debruçamos sobre a produção de sentidos na relação entre o dizer e o não-dizer, refletindo sobre o silêncio ${ }^{7}$ nestes gêneros de humor gráfico (ORLANDI, 1992).

O discurso no cartum e nas tiras deve ser entendido, de acordo com nossa concepção, segundo a definição de Van Dijk (2008, p. 12), não como uma análise de "objeto verbal autônomo, mas também como uma interação situada, como uma prática social ou como um tipo de comunicação numa situação social, cultural, histórica ou política”. Identificando os processos sócio históricos, a ideologia presente e, ainda, vislumbrar as formações discursivas a partir de uma análise formal dos elementos que a compõe. Isto permitirá tornar visível o que está invisível, relacionando o que está dito com o que não está dito ou que poderá dizer algo mais (ORLANDI, 2009).

Assim, utilizaremos um método de estudo baseado em uma análise contextual e descritiva do cartum/ tira em que serão observados os atos e ações descritos por ela através da linguagem verbal e não-verbal, orientado da seguinte forma:

a) Contextualizar o cartum/ tira, de forma que sejam esclarecidos a situação e o uso dos personagens envolvidos;

b) Identificar os aspectos discursivos nestes gêneros de humor gráfico e os elementos visuais que, por sua vez, representam as formações ideológicas em uma dialética construtiva;

c) Identificar os pontos de coincidência com aquilo que não é dito e que provoca uma desestruturação do sentido real, tendo o humor como fator constituinte da significação;

d) Perceber as relações entre a imagem e a construção de sentido por meio da memória e as críticas à luta de classes (ENGELS, 1982);

e) A relação entre a concepção do intelectual orgânico (GRAMSCI, 2001) e as formações ideológicas dos cartunistas.

\footnotetext{
${ }^{7}$ Ao descrever o silêncio, Orlandi (1992) considera que os efeitos de sentido como um lugar de múltiplos sentidos, daquilo que não é apreensível, que se torna visível a partir do invisível, onde o não-dito possui uma relação fundamental com aquilo que é dito e assim determina as formas do silêncio no movimento dos sentidos.
} 
Quando tratamos da luta de classes nas representações de Henfil, procuramos identificar os agentes construtores de sentido no materialismo histórico, numa luta contínua de oprimidos contra opressores por meio do viés humorístico. O humor no século XX, por sua vez, é refinado, deixando algo implícito, quase sempre recorrendo à memória, assim,

O humor serve, na verdade, de máscara: ele permite expressar o inconfessável sob uma forma socialmente aceitável e que se liberte das amarras de uma cultura que é, por outro lado, valorizada. O humor tem, assim, um aspecto liberador e igualmente catalisador da situação [...] $\mathrm{O}$ humor é um procedimento de dessacralização, de desencantamento parodístico: ele implica a dúvida, o ceticismo, a precariedade; contudo, não veicula nenhuma intenção sacrílega e blasfematória. (MINOIS, 2003, p. $565)$.

Segundo Engels (1982), a luta de classes está relacionada ao desenvolvimento histórico da humanidade. Afinal, a evolução da sociedade só se concretizou através da produção material para satisfazer suas necessidades básicas e os partidos são expressões políticas burguesas, proletárias ou do campesinato.

Figura 1: Henfil, Orelhão

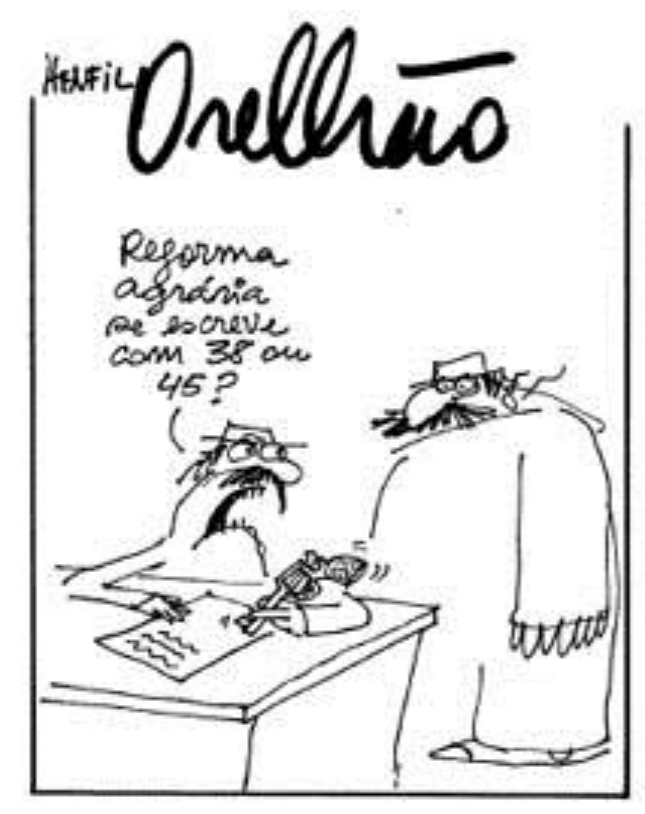

Fonte: https://www1.folha.uol.com.br/folha/ilustrada/ult90u54645.shtml, Acesso em 20 ago 2018.

Esta alusão estre expropriados e expropriadores pode ser percebida no personagem Orelhão (fig. 1) criado em 1983. Ele é operário, representante do movimento sindicalista, e está quase sempre numa atitude de ouvinte, como seu próprio nome indica, apresentando 
críticas à economia, à cidade, à realidade social ou à política através deste posicionamento (Acervo O Globo, 2018).

$\mathrm{Na}$ imagem (fig. 1), Henfil apresenta os conflitos de interesses do campesinato e das autoridades - ou dos representantes delas - reforçado pela linguagem verbal: "Reforma agrária se escreve com 38 ou 45?" O humor reside em torno do núcleo verbal e na maneira como o primeiro indivíduo segura a arma, fazendo alusão a um lápis. O segundo, por sua vez, não manifesta reação, permanecendo a dúvida em torno da indagação do primeiro. A resposta está subentendida, pois refere-se à violência, ou seja, a reforma agrária não ocorrerá pois representa ameaça contra os interesses de uma classe dominante: a latifundiária. Embora não seja evidente, esta constatação está implícita ou não-dita, uma vez que a reforma agrária implica na concessão de direitos à posse de terra para os camponeses, porém o Estado burguês não irá conceder tal acesso, uma vez que a prestação de serviços aos latifundiários e empresários capitalistas ainda é lucrativa (MARX \& ENGELS, 1982) ${ }^{8}$.

Henfil afirma por meio dos silêncios ou do dito e o não-dito que não haverá mudanças entre a burguesia e o campesinato, há apenas a manutenção dos privilégios da primeira sob os meios coercitivos que garantem a perpetuação das desigualdades. Entre as concepções do dito e do não-dito nos discursos, Orlandi (2009) cita outra forma de trabalhar o não-dito na Análise de Discurso. Trata-se do silêncio (ORLANDI, 1992). O silêncio não no sentido de qualidade física, mas como um lugar "de recuo necessário para que se possa significar, para que o sentido faça sentido" (ORLANDI, 2009, p. 83). Ao descrever que o sentido de algo pode ser outro, Orlandi chama-o de silêncio fundador, embora considere que existem outras formas de silêncio que "atravessam as palavras, que "falam" por elas, que as calam" (ORLANDI, 2009, p. 83). Neste sentido, acrescenta-se que o silêncio fundador é:

[...] o silêncio que existe nas palavras, que as atravessa, que significa o nãodito e que dá um espaço de recuo significante, produzindo as condições para significar. O silêncio como horizonte, como iminência do sentido, é a respiração da significação para que o sentido faça sentido. (ORLANDI, 2009, p. 128).

O silêncio, segundo Orlandi, nunca é implícito, ou seja, ele não depende daquilo que é dito, mas daquilo que é “apagado, colocado de lado, excluído, ele não deriva do sentido das palavras" (D’ATHAYDE, 2010, p. 53). O silêncio indica que o sentido pode ser outro.

\footnotetext{
${ }^{8}$ Ressaltamos que um dos motivos para o Golpe de 1964 está nas reformas de base promovidas por João Goulart, dentre elas: a reforma agrária.
} 
Figura 2: HENFIL. A volta do Fradim

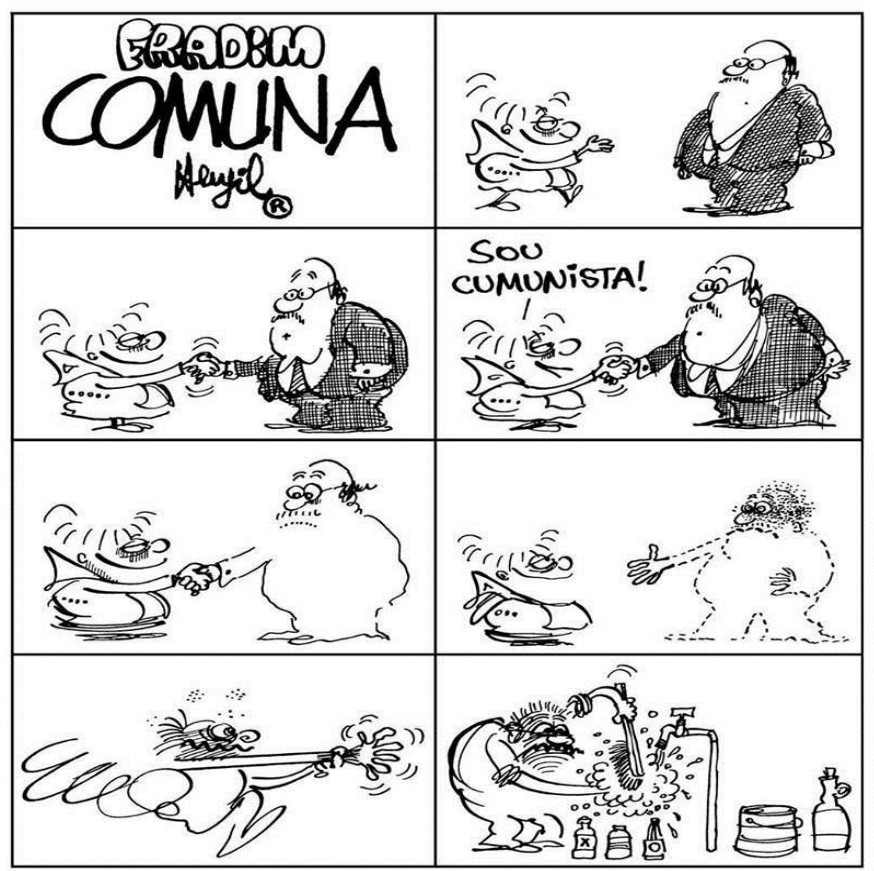

Fonte: Disponível em: http://www.geografiaparatodos.com.br/index.php?pag=captulo_2_a_guerra_fria. Acesso em 20 ago 2018.

Na fig. 2 acompanhamos um plano sequência composto por sete quadros nos quais o discurso se desenvolve. O Fradim é um dos personagens criados por Henfil, composto por dois frades - Baixinho e Cumprido - que fazem críticas à moral, à Igreja Católica e as convicções políticas.

Na tira, percebemos que um dos fradins - Baixinho, o alter ego de Henfil - dirige-se para cumprimentar outro sujeito. No terceiro quadro, ele se apresenta como comunista, mantendo o aperto de mãos. Na sequência, o outro sujeito começa a desaparecer após o cumprimento e corre para lavar as mãos no penúltimo e no último quadro. Após esta descrição, podemos elaborar algumas proposições:

a) O fradim apresenta-se como "cumunista", logo percebemos uma contradição entre a posição religiosa e a posição política. $\mathrm{O}$ cartunista também utiliza uma linguagem informal, denotando desprezo pelo outro;

b) A indumentária do outro indivíduo - terno e gravata - indica um posicionamento social diferente, deduzindo que ele possa ser um empresário capitalista devido a sua reação ao toque "cumunista". 
Temos assim uma possível oposição proletariado x burguesia uma vez que o fradim representa as concepções ideológicas de Henfil. A reação do sujeito indica o receio da desintegração do sistema capitalista vigente, já que ele é o próprio representante desta classe e defende a manutenção do equilíbrio econômico e competitivo.

O sorriso sarcástico do fradim demonstra a intenção de desestabilizar a ordem social competitiva, estabelecendo um clima de tensão entre eles. A solução viável pelo empresário capitalista, ao lavar as mãos, é uma tentativa de se livrar do contato comunista como se o mesmo fosse uma doença contagiosa. Essa atitude é uma forma de afrontar a burguesia e o status quo vigente, contrário a organização do proletariado no século XIX. Marx \& Engels (1982), ao analisar as revoluções de 1848-49 na Alemanha, cita a formação de uma união entre o proletariado e a burguesia, estendendo-lhe as mãos e promovendo a conciliação. Esta união apenas esconderia seus reais interesses em desfavorecer a classe trabalhadora. Segundo Marx \& Engels (1982), para adquirir hegemonia, a organização do proletariado precisa ocorrer por meio da política. Neste caso não há consenso, apenas repulsa.

Figura 3: HENFIL. Orelhão

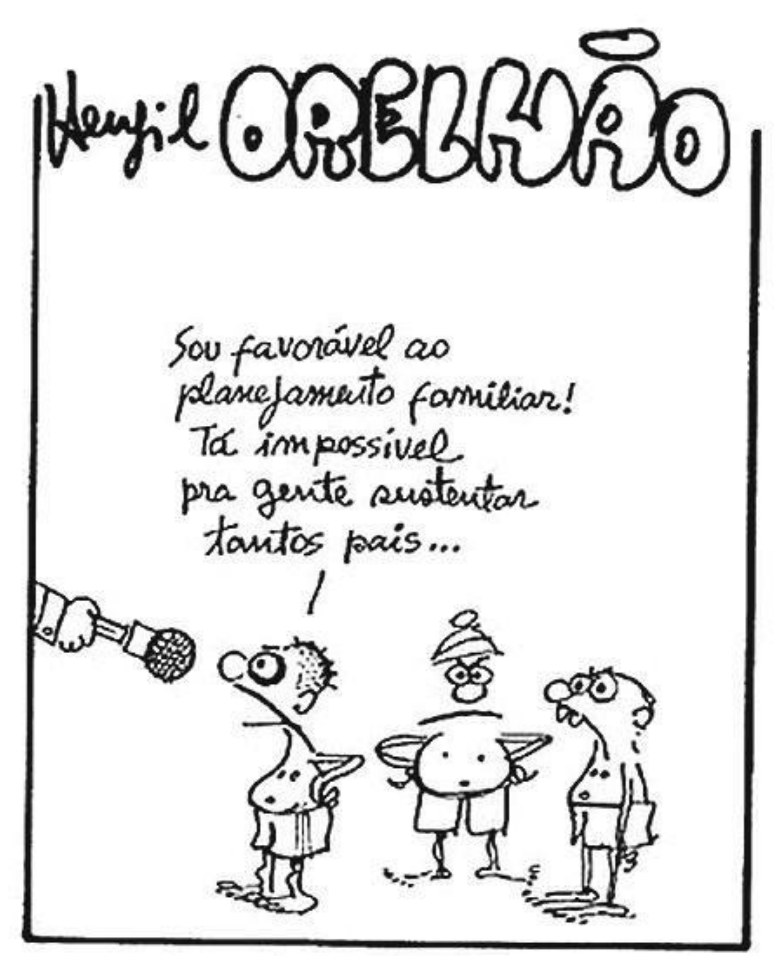

Fonte: Disponível em http://consciencia.net/henfil/. Acesso em 20 ago 2018. 
A próxima análise (fig. 3) trata-se de um grupo de três crianças indignadas, as quais concedem entrevista a um repórter (Orelhão). A indignação das crianças é denotada pela expressão facial e corporal - sobrancelhas franzidas, bocas cerradas e mãos apoiadas na cintura, seguida do relato da criança ao microfone do repórter. Ao afirmar que é favorável ao planejamento familiar, a criança demonstra que não é ingênua e surpreende no término do relato com um final inesperado, constituindo o sentido de humor no enunciado "Tá impossível pra gente sustentar tantos pais...”. No encerramento da afirmação deduzimos que o cartum se refere a um acontecimento real, relacionado à mendicância infantil, mas não necessariamente a um tempo-espaço utilizando figuras de conhecimento público e pode ser interpretado em diferentes épocas, pois trata-se de uma realidade social presente no cotidiano dos cidadãos das grandes cidades. O cartum nos remete ao conceito de Gramsci relacionado ao fetiche do Estado - aquele que é paternalista e proporciona direitos, mas também ao Estado autocrata (FERNANDES, 1987) - aquele que possui privilégios para a acomodação de interesses burgueses e superexploração da força de trabalho. Em ambas as definições percebemos a miséria gerada pela desigualdade social como instrumento de manutenção do domínio estabelecido sobre as classes dominadas, numa espécie de ciclo. Podemos recorrer também a Engels (1982) quanto às formas de dominação burguesas que inviabilizam o desenvolvimento da classe proletária.

Lembramos que o termo "proletário" foi utilizado inicialmente durante o Império Romano para se referir aos cidadãos que tinham apenas a sua prole como propriedade para arregimentar o exército imperial. O termo sempre teve utilização depreciativa até o século XIX, quando passou a designar uma classe de trabalhadores urbanos. A imagem (fig. 3) pode representar essa característica dúbia do termo: o grupo de crianças (prole) criados para engrossar não mais as fileiras do exército, mas o aumento dos casos de mendicância com a finalidade de colaborar nas despesas familiares. Entretanto, o termo também representa os filhos de proletariados urbanos desempregados ou com rendas insuficientes, ou seja, também representam uma classe em si.

É neste universo lúdico que se manifestam o imprevisto, o imprevisível, o não-dito e os silêncios que, consequentemente, produziram os efeitos de humor (D'ATHAYDE, 2010). Os efeitos de sentido são percebidos através das metáforas que se manifestam em um plano humorístico como uma condição de deixar o não-dito e o silêncio como um equívoco proposital, um espaço de deslocamento, de transformações e de realocações de novos 
sentidos. A transmutação de uma coisa em outra, a tomada de sentidos não necessariamente corretos sob o ponto de vista ocidental e cultural constitui uma espécie de matéria-prima para os cartunistas (PONTES, 1990) que, associada aos conceitos expostos por Orlandi (1992; 2009), provocam a possibilidade de estruturação de um conceito mais abstrato a partir de um conceito concreto.

\section{QUINO}

Joaquin Salvador Lavado conhecido pelo apelido Quino, nasceu na província de Mendoza, na Argentina, em 1932, tendo feito sua primeira publicação no semanário Esto es, de Buenos Aires e posteriormente em outras editoras como: Usted, Panorama, Adam, Atlântida, Che, jornal Democracia, entre outras (QUINO, 2018). Em 1963, publica seu primeiro livro: Mundo Quino e, a partir de 1965, o periódico El Mundo publica as tiras de Mafalda $^{9}$, sua principal personagem (QUINO, 2018).

Nesta parte do estudo, propomos uma análise de algumas tiras da Mafalda, numa tentativa de construir um discurso crítico relacionado a uma espécie de responsabilidade artística que, confere ao autor um engajamento político. E assim, perceber nas estruturas, questões relacionadas à memória, à constituição de gêneros, luta de classes e os silêncios inclusos neste gênero do humor gráfico.

A memória embora seja entendida como um fenômeno individual, também pode ser compreendido como um fenômeno coletivo e social, ou seja, ela está sujeita a modificações ou mudanças. Há diversos estudos que relacionam a memória a uma condição determinada por lugares, acontecimentos vividos ou indivíduos presentes em determinado espaço-tempo (MIANI, 2011). Porém, ela será observada sob o ponto de vista de acontecimento gravado em virtude de algo que reforça sentimentos de pertencimento ou de repulsa de um grupo. A memória se constitui a partir da análise destas tiras como uma forma, muitas das vezes não de denúncia, mas de conformidade e que segundo Pollak (1989), a memória é construída

\footnotetext{
${ }^{9}$ Mafalda é uma menina de sete anos e vive em Buenos Aires. Ela tem grandes preocupações com questões sociais e políticas. Filha de uma típica família da classe média argentina, Mafalda representa o anticonformismo da humanidade, mas acredita em sua própria geração. Ela repudia a injustiça, a guerra, as armas nucleares, o racismo, e o convencionalismo e até conformismo do mundo adulto, e, obviamente, a sopa (Batista, 2010). As suas paixões são os Beatles, a paz, os direitos humanos e a democracia (Batista, 2010). Ela não é uma heroína, mas sim uma anti-heroína (Batista, 2010). Ela não possui intenção altruísta, mas critica comportamentos e situações e põe a sociedade em questionamento. O caráter subversivo da Mafalda apresenta fatores de identidade cultural e nacional e também, as questões relacionadas ao discurso político realizado durante o chamado "Anos de Chumbo" no Brasil.
} 
socialmente em que são gravados, excluídos ou recalcados determinados fatos e reorganizados em uma nova lógica, quando se trata de uma memória herdada. Isto favorece um estreitamento entre a própria memória e o sentido de identidade da qual:

Podemos portando dizer que a memória é um elemento constituinte do sentimento de identidade, tanto individual como coletiva, na medida em que ela é também um fator extremamente importante do sentimento de continuidade e de coerência de uma pessoa ou de um grupo em sua reconstrução de si (POLLACK, 1989, p. 6).

A próxima imagem (fig. 4) reforça a ideia de identidade social e memória, e está dividida em três quadros, sendo o primeiro introdutório; o segundo, lança a problemática através da indagação: "Sabe por que este mundo é bonito?"; e o terceiro e último quadro, que encerra a tira, fornece todo o entendimento da trama. No primeiro quadro, Mafalda apresenta o globo terrestre ao seu ursinho de pelúcia e, este, por sua vez, encontra-se inanimado em todos os quadros, apenas observando as considerações da Mafalda.

Figura 4: Quino. Mafalda
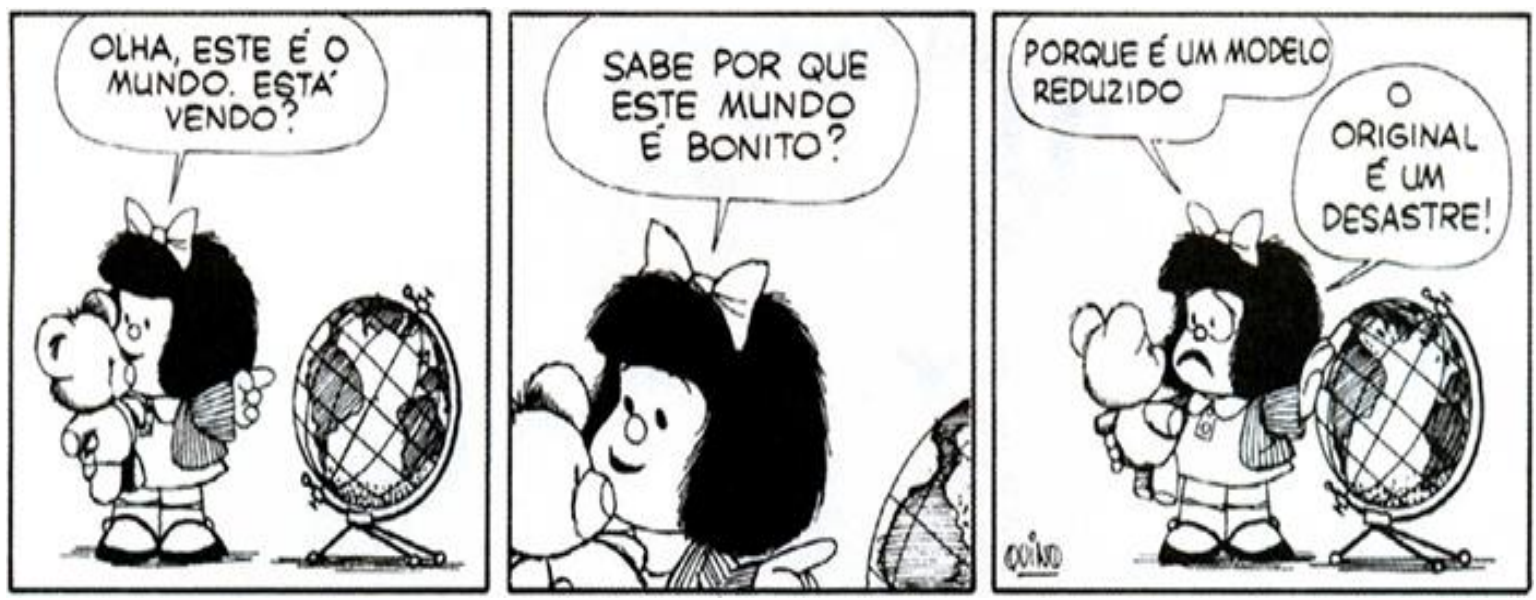

Fonte: Toda Mafalda, 2012.

Ainda no primeiro quadro, o globo terrestre apresenta a América Latina nitidamente apontada pela Mafalda, como uma forma de demonstrar um sentido de pertencimento ou nacionalidade. No segundo quadro, ela indaga o urso de pelúcia: "Sabe por que este mundo é bonito?". O terceiro quadro encerra a tira, fornecendo o elemento humorístico cuja resposta refere-se ao globo terrestre, que representa o mundo, sendo mais bonito porque é uma réplica 
em miniatura. Ali, há uma ideia pessimista do mundo como um todo, como um espaço destituído de belezas seja pelas guerras provocadas, seja pela condição social e econômica das mais variadas nações, demonstradas também pelas expressões faciais de Mafalda. Na tira, ela levanta questionamentos envolvendo aspectos sociais, econômicos e políticos e, embora não estabeleça um período temporal específico, possui características atuais marcantes sobretudo aquelas relacionadas a escassez de recursos e diferenças econômicas. Logo, Mafalda propõe uma reflexão de classes a partir de seu universo lúdico, como percebemos nas figuras 4 e 5 .

Discutindo as questões relacionadas às identidades sociais criadas apresentadas na Mafalda, entendemos que é uma prática social não apenas relacionada à identidade cultural (língua, valores adquiridos pelas diversas instituições sejam elas religiosas, educacionais ou familiares), e que consequentemente produz estereótipos sociais que cristalizam determinados grupos, como pode ser observado na figura 5.

Figura 5: Quino. Mafalda
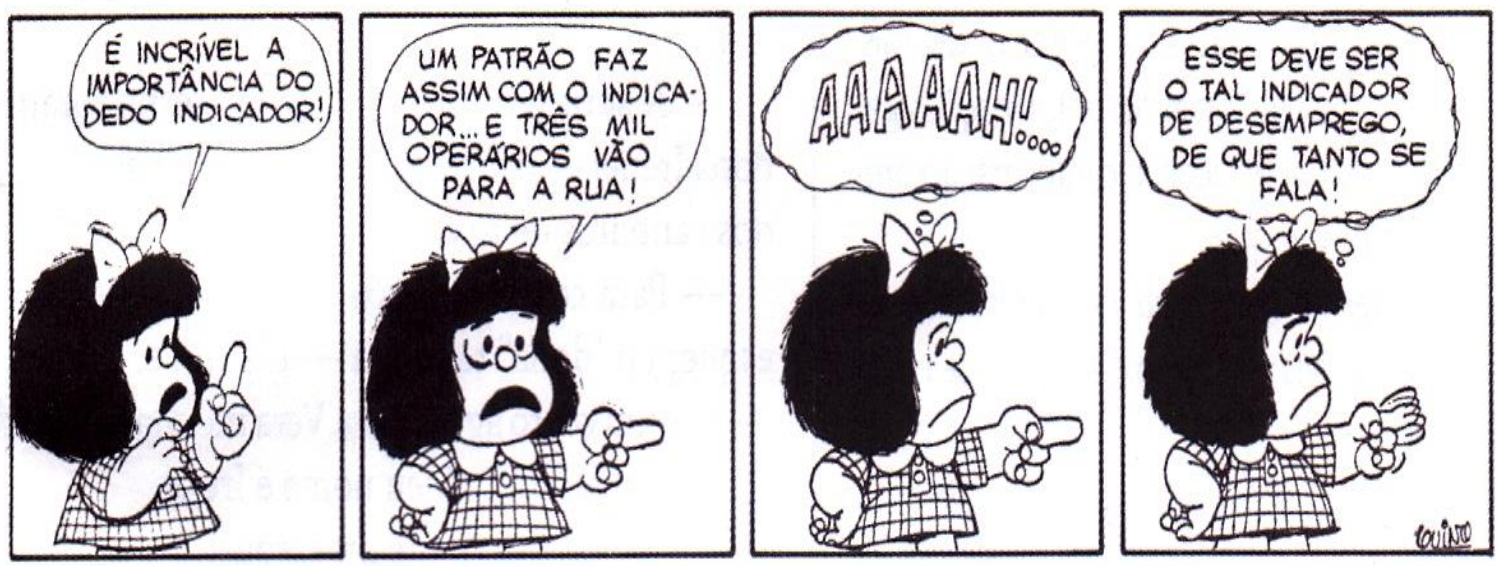

Fonte: Toda Mafalda, 2012

Este processo de conscientização das massas pode ser compreendido através da interpretação da Mafalda ao associar o dedo indicador da mão com o indicador de desemprego. A imagem é dividida em quatro quadros:

a) O primeiro introdutório, sobre a importância do dedo indicador;

b) O segundo demonstra a utilidade do dedo indicador para o empresário capitalista. O movimento dele indica a demissão de três mil operários; 
c) $\mathrm{O}$ terceiro quadro, traz o momento em que Mafalda compreende a importância do dedo indicador;

d) O quarto e último quadro, Mafalda deduz que o dedo indicador é o indicador de desemprego.

Desta forma, a tira realiza uma crítica aos índices de desemprego e a atitude do empresário capitalista que demite massas de operários em detrimento de interesses pessoais ou corporativistas. A luta da classe operária contra a exploração capitalista é política (MARX, 2012), portanto essa luta é consciente, mas sob o ponto de vista da personagem, é apenas uma observação do poder que a burguesia exerce sob o proletariado. Utilizando a necessidade da classe trabalhadora como condição de barganhar vantagens. Mais uma vez a tira apresenta características universais e extremamente atuais no que refere aos interesses do proletariado, pois na "sociedade atual, os meios de trabalho constituem monopólio da classe capitalista; a dependência da classe trabalhadora, condicionada por esse fato, é a causa da miséria e da servidão em todas as suas formas” (MARX, 2012 p. 87.). Portanto:

A propriedade privada dos meios de produção, que outrora foi o meio de assegurar ao produtor a propriedade de seu produto, tornou-se hoje o meio de expropriar os camponeses, os artesãos e os pequenos comerciantes e conferir os não trabalhadores-capitalistas, grandes proprietários fundiários a posse do produto dos trabalhadores (MARX, 2012, p. 91).

Figura 6: Quino. Mafalda
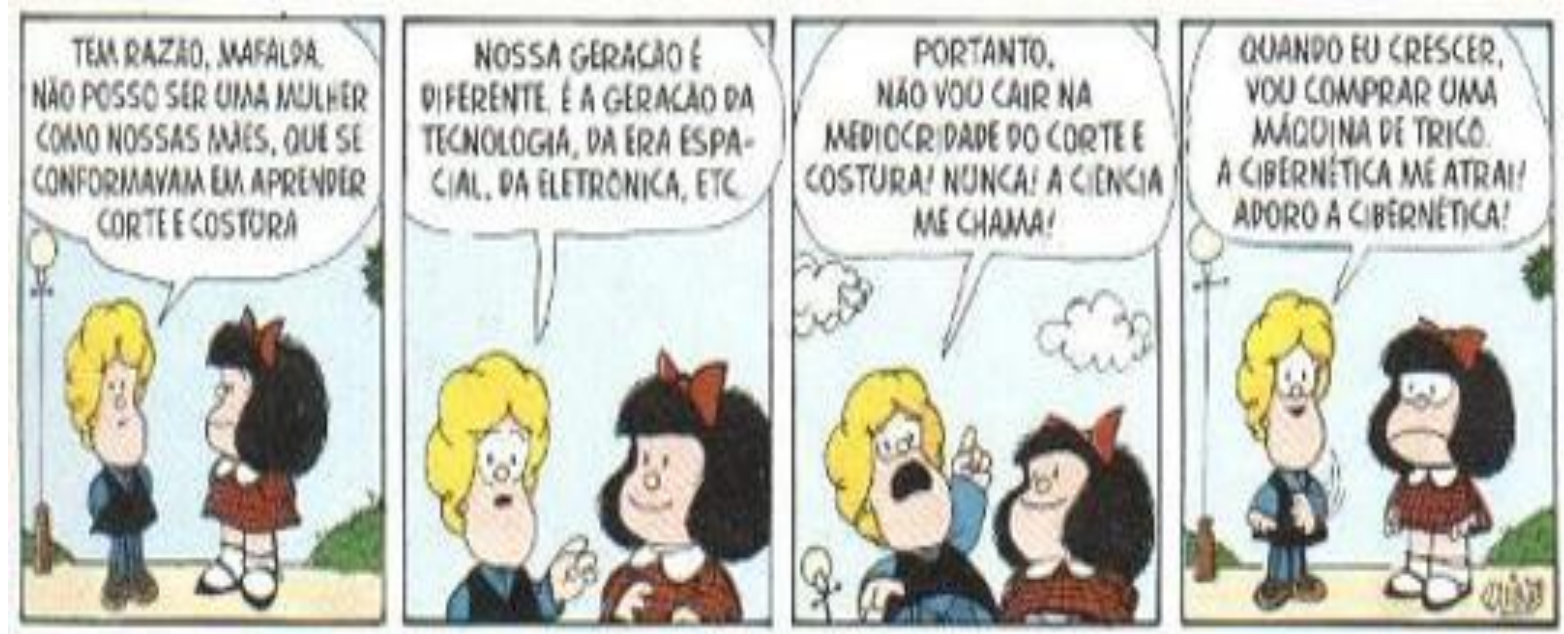

Fonte: Toda Mafalda, 2012 
A imagem (fig. 6) apresenta um discurso diferente, criticando o posicionamento da mulher na sociedade por meio de um diálogo entre Susanita e Mafalda. A tira novamente é dividida em quatro quadros nas quais deduzimos que:

a) A narrativa apresenta as concepções de Susanita a respeito conformismo feminino quanto a opinião e a educação das gerações anteriores, as diferenças em relação à sua genitora e um discurso de superação e mudança, modificando, inclusive, o ângulo do desenho, para valorizar a altivez de Susanita.

b) O último quadro fornece o elemento humorístico, ou seja, o discurso de Susanita apresenta interpretações distorcidas do empoderamento feminino. Ela apenas reforça o conservadorismo, enquanto Mafalda decepciona-se com a amiga.

Ao descrever estes elementos nos tópicos, podemos perceber que a personagem Susanita, difere-se da Mafalda quanto ao posicionamento ideológico e vocação política, possuindo aspirações superficiais, demonstrando maiores preocupações em seus interesses pessoais:

Susanita é egoísta ao máximo e briguenta por vocação. Tem o seu futuro totalmente planificado: um casamento magnífico, um marido com uma boa condição econômica e muitos, muitos filhos. Estas são suas paixões. As coisas que odeia são mais numerosas: os pobres dão-lhe nojo, quase tanto quanto o Manolito ${ }^{10}$, e detesta as reflexões da Mafalda. Obviamente, não está nem aí com o destino do mundo (MAFALDA, 2018).

Percebemos que as ideias de Susanita possuem um caráter altamente conservador e burguês devido aos elementos apresentados e, embora não tenha reações ou diálogos, Mafalda possui um comportamento diferente, pois os antagonismos presentes nas discussões de gênero e classes resultam em uma luta de opressores x oprimidos. A trajetória de Mafalda assemelhase a alguns pontos discutidos por Marx em relação às atribuições do Partido Socialdemocrata, representando um combate:

\footnotetext{
10 Manolito é um dos personagens criados por Quino, amigo de Mafalda. Manolito é bruto, ambicioso e materialista, mas, no fundo, com um grande coração. De todos os personagens, ele e a Susanita são os únicos que realmente sabem o que querem da vida. No seu caso, uma enorme rede de supermercados. Admirador de Rockefeller, as suas paixões são tão fortes como o seu ódio, como o que tem dos hippies - entre os quais inclui os Beatles - e da Susanita (MAFALDA, 2018).
} 
[...] portanto, não por novos privilégios e imunidades de classe, mas pela abolição do domínio de classe e das próprias classes e por iguais direitos e iguais deveres para todos, sem distinção de sexo e ascendência. Partindo dessa concepção, ele combate na sociedade atual não apenas a exploração e a opressão do trabalhador assalariado, mas toda forma de exploração e opressão, seja ela voltada contra uma classe, um partido, um sexo ou uma raça (MARX, 2012, p. 92).

Assim, ainda que as relações de classes não sejam abordadas diretamente, as tiras apresentam outra dimensão do silêncio, remetendo a uma incompletude, em que "todo dizer é uma relação fundamental com o não-dizer" (ORLANDI, 1992, p. 12) e a utilizando-se de uma carga simbólica para correlacionar com os acontecimentos. É a partir da construção alegórica do interesse de Susanita pela ciência, uma metáfora da subserviência feminina, é que observamos mais uma vez a presença do silêncio (ORLANDI, 1992) produzindo este deslocamento de sentido. Há um desejo de unicidade em uma relação do simbólico com a visualidade proposta pela iconografia da tira.

\section{CONCLUSÃO}

Orlandi (2009) se refere ao dito e ao não dito - ou o silêncio, conforme afirmamos anteriormente, nos discursos como meio de dizer algo nas entrelinhas, podendo possuir dois ou mais significados. A ideologia presente nas tiras e nos cartuns fazem parte da constituição do sentido e é um reflexo das formações ideológicas ${ }^{11}$ do sujeito do qual fala Fiorin (2001) e logo, estas formações ideológicas "correspondem a uma formação discursiva, que é um conjunto de temas e de figuras que materializa uma dada visão de mundo" (FIORIN, 2001, p. 32). Assim, concordamos com Miani (2007, p. 7): "a ideologia resulta de uma prática social, portanto não é subjetiva, no sentido de oposição a objetiva. Ela nasce da atividade social dos homens no momento em que estes procuram representar essa atividade para si mesmos."

Sendo assim, entendemos que a ideologia exposta nas tiras e nos cartuns, utilizando o discurso humorístico, possui relação com as visões de mundo do autor, a qual descrevem Fiorin (2001) e Pêcheux (1987) como formações ideológicas que são apreendidas ao longo da existência através da língua inserida em um curso sócio-histórico. A ideologia é uma espécie

\footnotetext{
${ }^{11}$ Segundo Fiorin (2001, p. 32) "uma formação ideológica deve ser entendida como uma visão de mundo de uma determinada classe social, isto é, um conjunto de representações, de ideias que revelam a compreensão que uma dada classe tem do mundo".
} 
de "consciência" de um grupo ou classe (VAN DIJK, 2008), ela é adquirida por meio de instituições como o Estado, a família, a Igreja e os meios de comunicação.

A partir desses autores, buscamos articular que a ideologia presente no discurso dos cartuns e das tiras não estão ligadas exclusivamente às formalidades da linguística ou a um discurso materialista como um instrumento técnico ou científico, mas como um processo discursivo, consciente e dotado de aspectos comunicativos que são percebidos através de uma carga simbólica, subjetiva e não verbal utilizada pelo cartunista. Assim, comunica temas considerados sérios, sem a rigidez formal da linguagem convencional.

As críticas expostas por Quino e Henfil buscam um consenso na sociedade civil, objetivando a hegemonia e a democracia envolvendo valores morais e sacrifícios numa revolução permanente. Tais valores são expostos através das ironias, do humor e dos silêncios contidos nos cartuns como: altruísmo, denúncias de abusos e liberdades ideológicas. Os sacrifícios podem ser percebidos durante as ditaduras, que forneceram os subsídios necessários aos cartunistas para empreender uma luta para ocupação dos espaços nos periódicos e em confrontos diretos aos regimes impostos. Fora dos anos da ditadura, a mensagem de resistência e luta estão direcionadas as mais diversas instituições de controle social.

Henfil e Quino podem ser considerados os intelectuais orgânicos da classe trabalhadora devido às circunstâncias - aos recentes mecanismos de dominação e os novos comportamentos da sociedade, às suas convicções político-partidárias e as representações que procuram levar críticas às mais diversas instituições, distanciando-se do positivismo cientificista:

Todo grupo social, ao nascer do terreno originário de uma função essencial no mundo da produção econômica, cria também, organicamente, uma ou mais camadas de intelectuais que conferem homogeneidade e consciência da própria função não apenas no campo econômico, como também no social e político: o empresário capitalista gera junto consigo o técnico da indústria, o cientista da economia política, o organizador de uma nova cultura, de um novo direito etc (GRAMSCI, p. 15, 2001).

O intelectual orgânico é aquele que faz parte de um organismo vivo, em constante mudança, ligados às questões trabalhistas, as organizações política e culturais:

Conscientes de seus vínculos de classe, manifestam sua atividade intelectual de diversas formas: no trabalho, como técnicos e especialistas dos conhecimentos mais avançados; no interior da sociedade civil, para construir 
o consenso em torno do projeto da classe que defendem; na sociedade política, para garantir as funções jurídico-administrativas e a manutenção do poder do seu grupo social (SEMERARO, 2006, p. 378).

Entende-se por orgânico estes novos intelectuais que acompanham as dinâmicas da sociedade e possuem o conhecimento científico, filosófico e da ação política, numa relação interdisciplinar entre as questões trabalhistas e humanidades, pois fazem parte da mesma realidade, criando uma base educacional e formativa democrática sob um conceito de hegemonia:

Gramsci retrata a osmose profunda dos intelectuais com as camadas populares, reconhecidas como sujeitos ativos imbuídos de "espírito criativo", porque promove a universalização da intelectualidade. Quer dizer, está convencido de que todos têm a capacidade de pensar e agir, de elaborar conhecimentos, de acumular experiência, de ter uma sensibilidade, um ponto de vista próprio (SEMERARO, 2006, p. 379).

Devemos destacar que a capacidade intelectual não é monopólio dos dois cartunistas pois há uma reciprocidade entre o observador e o observado, entre sujeito e leitor, estabelecendo uma relação dialética na qual o sujeito aprende, apreende e ensina ao mesmo tempo. A relação do intelectual orgânico com as identidades sociais pode ser entendida como o indivíduo que se autoreconhece em uma determinada classe. Essas construções identitárias estão situadas entre os sujeitos, a memória, os sentidos e seus efeitos múltiplos que se efetivam em contextos únicos ou situações precisas e no diálogo com o outro. As representações de Henfil e Quino estão inter-relacionadas com saberes, ideologias e marcadas por dialogismos, produzindo novos significados por meio da linguagem verbal e visual. Ferreira (2004, p. 47) "considera a identidade como uma referência em torno da qual o indivíduo se autorreconhece e se constitui, estando em constante transformação e construída a partir de sua relação com o outro". Percebemos que os cartuns e as tiras de ambos os cartunistas levantam questões sociais relacionadas às diferenças de classes, que utilizam o humor para constituir o elemento reflexivo ou crítico nas propostas. As representações de gênero em Henfil, por meio de seus personagens, ainda se manifestam sob uma perspectiva heteronormativa. O plano de discurso apenas manifesta uma visão masculina a respeito dos variados assuntos, o que difere de Quino, cuja personagem realiza diversas reflexões sobre as relações sociais, a luta de classes e o posicionamento da mulher na sociedade, cujo eu lírico é feminino. 
Podemos entender que a acidez contida nas representações de Henfil possui um caráter mordaz e panfletário ${ }^{12}$, com uma intensa necessidade de fundamentar suas bases na luta do movimento trabalhista. A mensagem linguística é curta e direta, proporcionando uma comunicação informal e possibilitando o entendimento das grandes massas.

Com relação a Quino, as proposições de Mafalda possuem uma característica mais ponderada, porém não menos eficaz do ponto de vista da reflexão. As imagens quase sempre são compostas por uma mensagem linguística - com introdução, desenvolvimento e conclusão - como forma de identificação da situação ou personalidade, participando como estrutura de mediação na comunicação da imagem e constituindo-se também como elemento humorístico parcial ou total, porém não é um fator exclusivo de orientação de sentido.

Os cruzamentos entre os discursos presentes na Mafalda ultrapassam as simples questões familiares ou regionais. As preocupações demonstradas pela menina envolvem questões globais sobre um prisma que ainda conserva a ingenuidade infantil. São questionamentos que não envolvem sistemas comunicacionais complexos ou extensas reflexões, mas um convite para repensar comportamentos, atitudes sob a perspectiva de uma criança sem, contudo, parecer infantilizado ou medíocre.

As representações dos cartunistas pesquisados, em geral, possuem em sua estrutura um discurso ideológico que revela o ponto de vista de seu autor e, a maior parte de suas imagens apresentados neste estudo, a relação figura/fundo é diluída, pois a própria figura assume a posição principal de atenção ou ponto de fuga proporcionando ênfase ao assunto. $\mathrm{O}$ plano de fundo não recebe praticamente nenhum recurso de ornamentação, objetivando o destaque da figura como meio de concentração da crítica. Basicamente, percebemos que os cartuns analisados possuem a seguinte estrutura de construção:

1. Traço característico do cartunista ou estilo;

2. Presença ou ausência de volumes;

3. Planos de perspectiva ou de expressão;

4. Ausência do Plano de fundo;

5. Presença de elementos textuais (balões de fala, legendas etc.).

\footnotetext{
${ }^{12}$ Um cartum panfletário está associado ao ataque por meio de críticas irônicas ou satíricas, de caráter violento. Os panfletos remetem aos jornais radicais do século XIX.
} 
Os cartuns e as tiras trazem um discurso crítico, persuasivo e um caráter elucidativo que visa, sobretudo, manter o leitor informado e estimulá-lo na construção de um posicionamento crítico. Com relação à mensagem inclusa no cartum/tira, que aponta ao leitor a um determinado comportamento, consideramos que a persuasão da mesma se dá em um estágio pré-iconográfico descrito por Panofsky (2009). Há dois tipos de significados primários em uma mensagem - fatual e expressional. O primeiro é aquele percebido facilmente por estarmos familiarizados com os objetos representados e, o segundo, que é apreendido não por uma identificação com o objeto, mas por uma empatia que desperta um tipo de reação no indivíduo. Em um novo estágio, temos os significados secundários, no qual a mensagem pode apresentar uma combinação de elementos artísticos com conceitos e assuntos que resultam nas alegorias e histórias (PANOFSKY, 2009).

Ao insistirmos no caráter persuasivo do cartum/ tira, torna-se importante relacionar a ideologia como uma relação de poder. Nosso objetivo, ao concluir este artigo é afirmar que o cartunista ao produzir um desenho detém uma variada rede de estratégias culturais e simbólicas que permitem direcionar a informação, disseminando valores ideológicos (VAN DIJK, 2008). A mensagem inclusa no cartum e na tira pode: descrever, expressar, sinalizar, legitimar e até esconder sentidos e induzir a determinadas reflexões.

Neste sentido:

Considerar a imagem como uma mensagem visual composta de diversos tipos de signos equivale, [...] a considera-la como uma linguagem e, portanto, como uma ferramenta de expressão e de comunicação. Seja ela expressiva ou comunicativa, é possível admitir que uma imagem sempre constitui uma mensagem para o outro, mesmo quando esse outro somos nós mesmos. (JOLY, 2007, p. 55).

O não-dito e os silêncios incluídos no interior do cartum e das tiras cômicas são vistos como agentes fundadores de sentido que se fundamentam em uma estética da contradição no ambiente criado por seus autores. Através do discurso humorístico criam-se alegorias que contradizem o que realmente corresponde à realidade, dizendo algo por meio de entrelinhas, deixando implícito certas impressões. O silêncio pode ser um lugar de discordância e resistência, criando um universo lúdico dentro de uma lógica própria do humor gráfico: o exagero, a desproporção e a formalização com o grotesco.

Os cartuns e tiras de Henfil e Quino, através do humor, consolida-se como uma manifestação sociocultural que, através de um método que opõe o subjetivo e objetivo, 
levanta críticas e suscita reflexões. A partir das considerações nas análises deste texto, aproxima proposições complexas e as exibe em um plano de compreensão popular viabilizada por uma linguagem simples e direta. Assim, a partir das imagens apresentadas neste trabalho, percebemos que as formações ideológicas dos cartunistas subvertem o sentido, utilizando-se de silêncios para dizer algo a mais por meio dos cartuns e tiras. A memória se constitui como elemento de identidade, logo na historiografia regional, percebe-se as variações entre a memória coletiva e a memória afetiva em espaços e tempos distintos:

A memória é, sem dúvida, aspecto relevante na configuração de uma história local [...] a história local pode simplesmente reproduzir a história do poder local e das classes dominantes, [...] destacando a vida e obra de antigos prefeitos e demais autoridades. Para evitar tais riscos, é preciso identificar o enfoque e a abordagem de uma história local que crie vínculos com a memória familiar, do trabalho, da migração, das festas. A questão da memória impõe- se por ser a base da identidade, e é pela memória que se chega à história local (BITTENCOURT, 2011, p. 169).

A historiografia adquiriu novas percepções que estão além dos documentos registrados, definindo novos critérios que também podem atestar a veracidade da informação. A existência de uma história plural ou integrada possibilita a construção de um olhar que supere as superficialidades ou eventos isolados:

A História integrada parte de uma concepção processual da história que pressupõe a conjunção de múltiplas temporalidades para compor a explicação histórica, enfatizando simultaneamente aspectos de natureza econômica, política, social, cultural. Diferentemente da história temática (ou por eixos temáticos), a História integrada não abandona a pretensão de abordar toda a história, de todas as sociedades, tempos e lugares (CAIMI, 2009, p. 7).

Portanto, ao analisarmos as diferentes visualidades e discursos nos cartuns/ tiras, percebemos noções identitárias mais amplas, próximas do conceito gramscista sobre a figura do intelectual orgânico, sendo um dispositivo interdisciplinar mediador de questões do cotidiano que se materializa a partir das formações ideológicas do cartunista. No cartum/ tira encontraremos especificidades sociais e históricas reveladas não apenas através da linguagem, mas por toda a recorrência simbólica utilizada, produzindo efeitos de sentido múltiplos e construindo novas narrativas dentro da historiografia. 


\section{REFERÊNCIAS}

ACERVO O GLOBO. Na estreia de Henfil no GLOBO, o operário Orelhão ironiza o Dia do Trabalho, O Globo, São Paulo, jul. 2013. Disponível em: http://acervo.oglobo.globo.com/charges-e-humor/na-estreia-de-henfil-no-globo-operarioorelhao-ironiza-dia-do-trabalho-9041508\#ixzz54TdyW6m2 Acesso em: 17 abr. 2018.

BATISTA, Adriana Danielski. Interação de vozes em Mafalda. Anais do SITED Seminário Internacional de Texto, Enunciação e Discurso Porto Alegre, RS, setembro de 2010 Núcleo de Estudos do Discurso Pontifícia Universidade Católica do Rio Grande do Sul. Disponível em http://ebooks.pucrs.br/edipucrs/anais/sited/arquivos/AdrianaDanielskiBatista.pdf. Acesso em: 25 de abr. 2018.

BITTENCOURT, C. M. F. Ensino de História: fundamentos e métodos. 4. ed. São Paulo: Cortez, 2011.

CAIMI, F. E. Conversas e controvérsias: o ensino de história no Brasil (1980-1998). Passo Fundo: UPF, 2001.

CENTRO CULTURAL. Gibiteca Henfil. São Paulo, jan. 2018. Disponível em: http://www.centrocultural.sp.gov.br/gibiteca/henfil.htm. Acesso em: 11 abr. 2018.

D'ATHAYDE, E. M. Entre o dizer e o não-dizer: a charge política e a relação com o silêncio. Pelotas: Universidade Católica de Pelotas-RS, 2010. $111 \mathrm{f}$.

EAGLETON, Terry. Ideologia: uma introdução. Trad. Silvana Vieira, Luís Carlos Borges. São Paulo: Fundação Editora da UNESP, 2010.

ENGELS. Friedrich. Introdução à edição alemã de 1895 de "As lutas de classes em França de 1848 a 1850 de Karl Marx”. In: MARX, Karl \& ENGELS, Friedrich. Obras escolhidas. Tomo I. Lisboa/ Moscou: Avante!/ Progresso, 1982, p. 189-208.

FERNANDES, Florestan. A Revolução Burguesa no Brasil: ensaio de interpretação sociológico. Rio de Janeiro: Zahar Editores, 1987.

FERREIRA, Ricardo Franklin. Afro-descendente: identidade em construção. São Paulo: EDUC; Rio de Janeiro: Pallas, 2004.

FIORIN, José Luiz. Linguagem e ideologia. 7. ed. São Paulo: Ática, 2001.

FOLHA. Veja a lista de mortos e desaparecidos do regime militar. Disponível em https://www1.folha.uol.com.br/poder/2014/12/1560655-veja-a-lista-de-mortos-edesaparecidos-do-regime-militar.shtml Acesso em 29 ago 2018.

FONSECA. Joaquim da. Caricatura a imagem gráfica do humor. Porto Alegre: Artes e Ofícios, 1999. 
GRAMSCI, A. Cadernos do cárcere. Rio de Janeiro: Civilização Brasileira, 2001.

JOLY. Martine. Introdução à análise da imagem: a imagem, as palavras. 11 ed. Campinas: Papirus Editora, 2007. p. 115-123.

A imagem e sua interpretação. Lisboa, Portugal: Edições 70, 2003.

MACIEL, David. Notas sobre revolução passiva e transformismo em Gramsci. História Revista, Goiânia, vol. 11, $\mathrm{n}^{\mathrm{o}}$ 2, p. 273-299, jul/dez 2006. Disponível em: https://www.revistas.ufg.br/historia/article/viewFile/9063/6257. Acesso em: 10 abr. 2018.

MAFALDA ONLINE. Os protagonistas. Brasil, jan. 2018. Disponível em: <http://www.mafalda.net/index.php/PT/os-protagonistas> Acesso em: 21 jan. 2018.

MARX, Karl. Crítica ao Programa de Gotha. São Paulo: Boitempo, 2012.

MARX, Karl \& ENGELS, Friedrich. "Mensagem da Direção Central da Liga dos Comunistas". In MARX, Karl \& ENGELS, Friedrich. Obras Escolhidas, Tomo I. Lisboa/ Moscou: Avante!/ Progresso, 1982, p. 95-136.

MIANI, R. A. Charge: uma prática discursiva e ideológica. Intercom - Sociedade Brasileira de Estudos Interdisciplinares da Comunicação. XXIV Congresso Brasileiro da Comunicação. Campo Grande, set. 2001.11 f.

MINOIS, Georges. História do riso e do escárnio. Trad. Maria Elena O. Ortiz Assumpção. São Paulo: UNESP, 2003.

O GLOBO. Os personagens de Henfil. São Paulo, jan. 2018. Disponível em: https://infograficos.oglobo.globo.com/cultura/os-personagens-de-henfil/fradim10827.html\#description_text. Acesso em: 10 abr. 2018.

ORLANDI. Eni P. Análise de Discurso. 7 ed. Campinas: Pontes, 2009.

SP: Pontes, 2005.

Discurso e texto: formulação e circulação dos sentidos. 2. ed. Campinas, . As formas do silêncio no movimento dos sentidos. 2. ed. Campinas, SP: Editora da Unicamp, 1992.

PANOFSKY, Erwin. O Significado nas artes visuais. 3 ed. São Paulo: Perspectiva, 2009.

PÊCHEUX, Michel. Semântica e discurso: uma crítica à afirmação do óbvio. Trad. Eni Orlandi. Campinas, SP: Editora da UNICAMP, 1987.

Campinas, SP: Pontes, 1997.

O discurso: estrutura ou acontecimento. Trad. Eni P. Orlandi. 2. ed.

PINTO, Milton José. Comunicação e Discurso. São Paulo: Hacker Editores, 1999. 
POLLACK, M. Memória, esquecimento, silêncio. Revista Estudos Históricos, Programa de Pós-Graduação em História, Política e Bens Culturais (PPHPBC) da Escola de Ciências Sociais (CPDOC) da Fundação Getulio Vargas (FGV), Rio de Janeiro, vol. 2, n. 3, p. 3-15, jan/jun. 1989.

Disponível em http://bibliotecadigital.fgv.br/ojs/index.php/reh/article/view/2278. Acesso em: 18 abr. 2018.

PONTES, Eunice (Org.). A Metáfora. Campinas, SP: Editora da Unicamp, 1990.

PUNCH. History of the cartoon. Londres. Punch.co.uk. Disponível em: <http://punch.co.uk/contactus.html>. Acesso em: 10 fev. 2018.

QUINO. Biografia. Buenos Aires, jan. 2018. Disponível em: http://www.quino.com.ar/biografia/. Acesso em: 18 abr. 2018.

QUINO. Toda Mafalda. 2.ed. São Paulo: Marins Fontes, 2010.

SEMERARO, Giovanni. Intelectuais “orgânicos” em tempos de pós-modernidade. Cad. Cedes, Campinas, vol. 26, n. 70, p. 373-391, set./dez. 2006. Disponível em http://www.scielo.br/pdf/\%0D/ccedes/v26n70/a06v2670.pdf. Acesso em: 29 abr. 2018.

TEIXEIRA, Liliana Alicia Lavisse. A (DES) ORDEM DO DISCURSO DE MAFALDA: Uma análise da mulher nas tirinhas de Quino. FACOM-UFBA. VI Encontro de estudos multidisciplinares em $\quad 2010.2$ Disponível em: http://www.cult.ufba.br/wordpress/24421.pdf. Acesso em: 08 abr. 2018.

VAN DIJK, Teun A. Discurso e poder. São Paulo: Editora Contexto, 2008. 